\title{
Literary Translation as Semiotic Interpretation In the Light of
Philological Hermeneutics In the Light of
Philological Hermeneutics
}

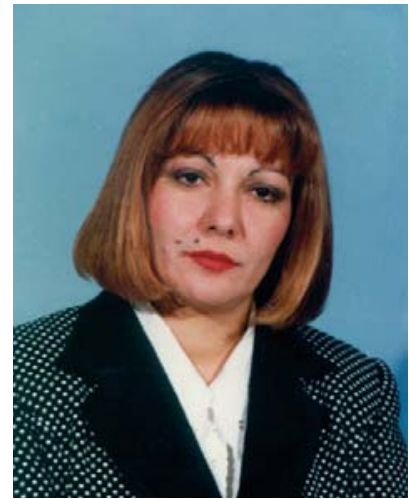

Diana Hambardzumyan

T $\mathrm{t}$ is a commonly accepted point of view nowadays that translating does not simply mean transfering. As once J.C.Catford stated, "In translation, there is substitution of TL meanings for SL meanings: not transference of TL meanings into the SL. In transference there is an implantation of SL meanings into the TL text. These two processes must be clearly differentiated in any theory of translation”. ${ }^{1}$ Susan Bassnett-McGuire interpreted this statement, on the one hand, as "a new stage of the debate on translation", on the other hand, as "a restricted one - as it implies a narrow theory of meaning. Discussion of the key concepts of equivalence and cultural untranslatability has moved on a long way since his book first appeared”. ${ }^{2}$

Every translator should bear in his/her mind: translating fiction accurately involves substituting not only the semantic layer of this or that language /SL/ vocabulary used in the specific text with the appropriate counterparts existing in the $\mathrm{TL}$, but also the peculiar aura created by the writer using the language in speech. Thus, Susan Bassnett-McGuire is absolutely right to conclude that the discipline of Translation Studies bridges the gap between the vast area of stylistics, literary history, linguistics, semiotics and aesthetics, but at the same time it is firmly rooted in practical application. ${ }^{3}$

It is a well-known fact that language and speech are separated from each other quite artificially, for the sake of investigation, insofar as language cannot but exist only in speech, and speech can only be realized on the basis of language and through language. Language units are considered to belong to both language and speech spheres. According to the semiotic concept, a linguistic sign consists of two planes: content and expression. Language is realized in speech as the content has its way of expression. Language, i.e. the content, is the signifier /signifiant/, speech, i.e. the expression, is the signified /signifie'/ plane of the sign.

The fact that language itself makes use of both the content and the expression planes as speech does, gives us grounds to investigate separate language units not only as belonging to merely language /the content plane/, but also appearing in speech /the expression plane/. Thus, in this respect language units such as: texts, word combinations, words, phonemes, phonesthemes, etc., being included into the 
sphere of language-speech dialectical unity, are considered to be a part of a linguistic sign. Thus, the relationship between linguistics and semiotics is obvious. As far as texts are concerned, semiotics deals with them as it is a philological study of various linguistic phenomena functioning in speech. In his book "Structuralism and Semiotics" T.Hawkes confirms that translation belongs to semiotics as far as the translation process "involves a whole set of extra-linguistic criteria also" ${ }^{4}$

In recent years translation, and specifically literary translation, is comprehended as "interpretation". More than four decades ago Roman Jakobson described translation as an interpretation of verbal signs by means of other signs in the same language /intra-lingual translation/, an interpretation of verbal signs by means of some other language /inter-lingual translation/, an interpretation of verbal signs by means of signs of nonverbal sign systems /inter-semiotic translation/.5

Thus, widely interpreted, literary translation as a product and process should be analysed alongside with the original which is also a product and process. It is a twosided object of investigation in philological hermeneutics.

According to Nazarova T.B., "discourse-oriented semiotics aims at typological investigation of narrative and has more to do with narratology, logic, cohesion and syntax". ${ }^{6}$ As far as structure-oriented semiotics is concerned, it "deals with schematic synopsizing of literary texts and owes its present-day worldwide recognition to the Russian scholar V. Propp, whose findings were later /in the 50s/ used as the basis of the structural-semiotic presentation of literary works". ${ }^{7}$

As has been mentioned above, the two equally essential components of the linguistic sign are content and expression, from the point of view of semiotics, the plot of the original invested in language units /the content/ cannot be investigated separately, taken out of its structure /the expression/. In addition to this, all the specific codes created by an author should be comprehended and adequately interpreted within a national-cultural context, then only decoded and reconstructed in the TL.

Contemporary scholars in semiotics believe that language units are inevitably defined by their extra-lingual relations. In respect of a literary work, its extra-lingual cultural background includes not only the historical epoch depicted in the work, the writer's world-view and his creative peculiarities, but his overall biographical data as well.

It is in this case that the linguopoetic analysis of a literary work enables the investigator, among other things, to go deep into the extra-lingual relations of linguistic signs, to single out those parts of the work and its translation, which are of literary, moral, ethical and aesthetic value in the work.

Thus, linguosemiotics is not only closely connected with philology, but is particularly essential to literary translation, which being quite a separate branch of investigation, combines the two aspects of philology: literary studies and linguistics. 


\section{References:}

1. Catford J.C., A Linguistic Theory of Translation, London, Oxford University Press, 1965, p.32-37.

2. Susan Bassnett-McGuire, Translation Studies, London, New York, Methuen \& Co, 1980, p.6.

3. Ibid. p.6-7.

4. Hawkes T. Structuralism and Semiotics. Berkeley, 1977.

5. Jacobson R. On Linguistic Aspects of Translation. In: On Translation ed.by Brower R.A. Cambridge, Mass., Harvard University Press, 1959, p.232-239.

6. Назарова Т.Б. Филология и семиотика: Современный английский язык. М., Высшая школа, 2003, с.168.

7. Ibid. p.168.

\section{9tnunltuunulyma punquiuanıpjnılin

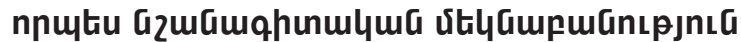

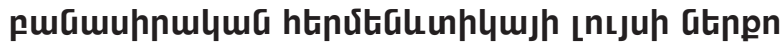

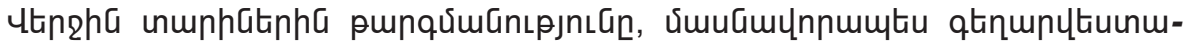

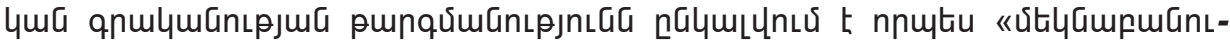

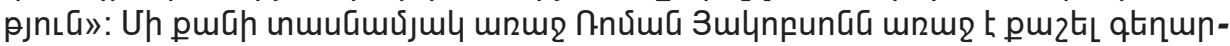

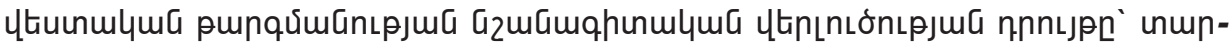

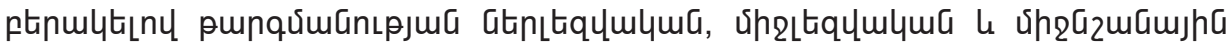

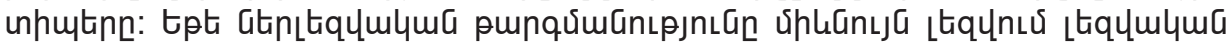

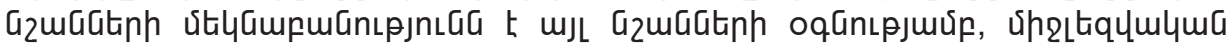

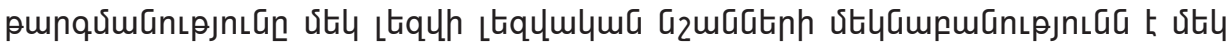

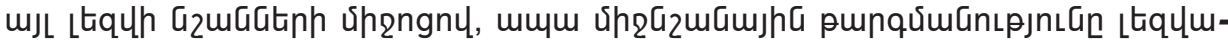

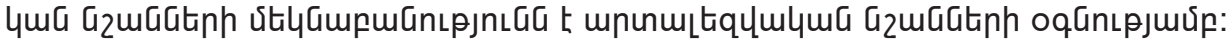

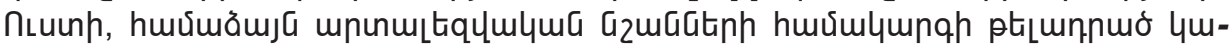

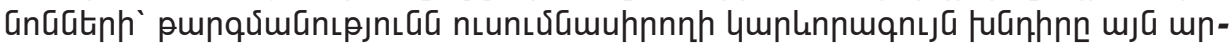

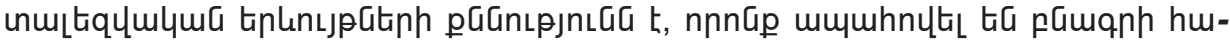

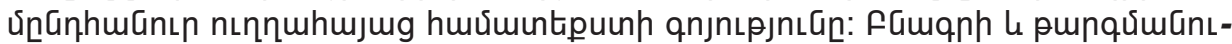

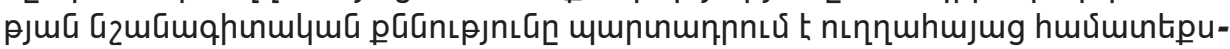

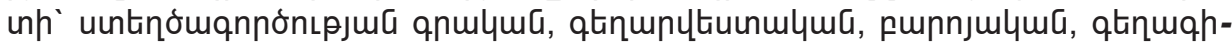

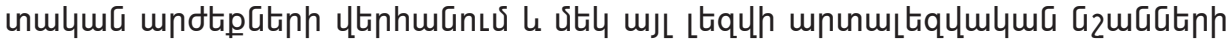

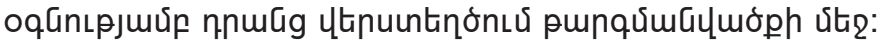

